\title{
Pesticide selectivity to natural enemies: challenges and constraints for research and field recommendation
}

\author{
Adeney de Freitas Bueno ${ }^{1}$ Geraldo Andrade Carvalho ${ }^{2}$ Antônio Cesar dos Santos ${ }^{3}$ \\ Daniel Ricardo Sosa-Gómez ${ }^{1}$ Débora Mello da Silva ${ }^{4}$
}

\author{
${ }^{1}$ Embrapa Soja, Londrina, PR, Brasil. E-mail: adeney.bueno@embrapa.br. "Corresponding author. \\ ${ }^{2}$ Universidade Federal de Lavras (UFLA), Lavras, MG, Brasil. \\ ${ }^{3}$ Dow AgroSciences Ltda, São Paulo, SP, Brasil. \\ ${ }^{4}$ Instituto Agronômico do Paraná, Londrina, PR, Brasil.
}

ABSTRACT: Pesticides are considered the first line of defense for the control of pests and diseases. At least in the short and medium term, the use of pesticides will remain an important strategy for pest management, allowing growers to produce crops of sufficient quality at low costs. A broad approach known as Integrated Pest Management (IPM) combines several different pest-control strategies, among which the combination of chemical and biological control stands out. It requires pesticides that achieve optimal control of target pests with minimal impact on the activity of biological control agents. Because of the dynamics of pest infestations, IPM routines are continuously adjusted by growers, requiring comprehensive information about pesticide effects on natural enemies. However, this information is not always available and often contradictory, which constrains the design of field recommendations. In this review, we focused on the importance of selective pesticides in IPM programs, and the effects of chemical pesticides on parasitoids, predators, and entomopathogenic fungi. We provided a detailed discussion of the challenges and constraints for research on pesticide effects on natural enemies, as well as for the resulting field recommendations.

Key words: IPM, biological control, chemical control.

\section{Seletividade de agrotóxicos nos inimigos naturais: desafios e restrições} para a pesquisa e recomendações de campo

\begin{abstract}
RESUMO: Para o controle de pragas e doenças, os agrotóxicos são considerados a primeira linha de defesa. Pelo menos no curto e médio prazo, o seu uso continuará a ser uma estratégia importante de manejo, permitindo aos produtores produzir com baixo custo e boa qualidade. O manejo integrado de pragas (MIP) combina várias estratégias diferentes de controle de pragas. Entre elas, a associação do controle químico e biológico tem grande importância. Isto depende de agrotóxicos que tenham um ótimo controle das pragas alvo, com minimo de impacto possível sobre a atividade dos agentes de controle biológico. Assim, devido à dinâmica de pragas, os produtores precisam de informações completas sobre os efeitos dos agrotóxicos sobre os inimigos naturais visando constantemente ajustar suas rotinas de MIP. No entanto, estas informações não estão sempre disponíveis, e quando encontradas, são muitas vezes contraditórias, o que prejudica as recomendações de campo. Nesta revisão, destacamos a importância de agrotóxicos seletivos em programas de MIP e seus efeitos sobre parasitoides, predadores e fungos entomopatogênicos. Ainda, discutiremos com mais detalhes os desafios e restrições para a pesquisa e recomendações de campo sobre seletividade de agrotóxicos.

Palavras-chave: MIP, controle biológico, controle químico.
\end{abstract}

\section{INTRODUCTION}

Among the beneficial organisms of agricultural importance, the natural enemies of arthropods are noteworthy for their contribution to reducing pest outbreaks. However, while there are many examples of successful biological control, chemical control is still widely used to safeguard profitable yields. Pesticides, such as insecticides, fungicides, herbicides and acaricides are important tools for crop management and play a significant role in agricultural production worldwide (BUENO \& BUENO, 2012). Nevertheless, chemical control is frequently overused, mainly in crops cultivated on a large scale, such as soybean (BUENO et al., 2011). It is current practice of soybean growers to apply insecticides without considering the recommended pest threshold level (SONG \& SWINTON, 2009). This incorrect use of agrochemicals is endangering the sustainability of important crops worldwide (SONG \& SWINTON, 2009; BUENO et al., 2011).

Overuse of non-selective pesticides in agriculture has several important adverse effects, of which the harm caused to biological control agents is the most relevant (CARMO et al., 2010a; FERNANDES et al., 2010). Among other negative effects, reduced activity of biological control agents usually leads to pest resurgence, occurrence 
of secondary pests and selection for resistance (FERNANDES et al., 2010). In order to mitigate those problems and to maintain agricultural sustainability in the medium and long term, Integrated Pest Management (IPM) is an alternative to prophylactic pest control. IPM is an ecosystem-based strategy focused on long-term prevention of pests using a combination of several different techniques (ZALUCKI et al., 2009), such as selective pesticides. Pesticides most suitable for IPM are those that combine optimal control of target pests with minimal impact on the activity of natural enemies (BUENO \& BUENO, 2012). Testing various pesticides, CORRÊA-FERREIRA et al. (2010) demonstrated the importance of using harmless pesticides. This study reported that the abundance of Chrysodeixis includens Walker (Lepidoptera: Noctuidae) was lowest on soybean plots when treated with the commercial baculovirus Anticarsia (AgMNPV). While this product does not directly target $C$. includens (Figure 1 ), it effectively prevented an outbreak of this species, being the most selective treatment without impact on the natural control agents. In contrast, chemical insecticides, due to their negative impact on natural enemies, resulted in a higher number of $C$. includens larvae. When emphasizing the importance of selective pesticides in agriculture, not only insecticides or acaricides should be considered, but also herbicides, fungicides, plant growth regulators, foliar fertilizers and other chemicals that might be applied to crop canopies (STECCA et al., 2016).

Despite the outlined importance of understanding pesticide effects on natural enemies of arthropods, the number of papers on this subject in major international journals of entomology has declined, due to their priority on novel issues of higher impact. Nevertheless, insecticide use in the field is an active process influenced by frequent introductions of new compounds; there are alterations of insecticide rates due to pest resistance, or the occurrence of new species, such as the recently identified Helicoverpa armigera Hübner (Lepidoptera: Noctuidae) in Brazil (GODOY et al., 2015). Because of this dynamic scenario, growers feel uncertain about the correct choice of pesticides, and often disregard pesticide selectivity when choosing a product. Therefore, constraints and challenges regarding pesticide effects on natural enemies with respect to research as well as

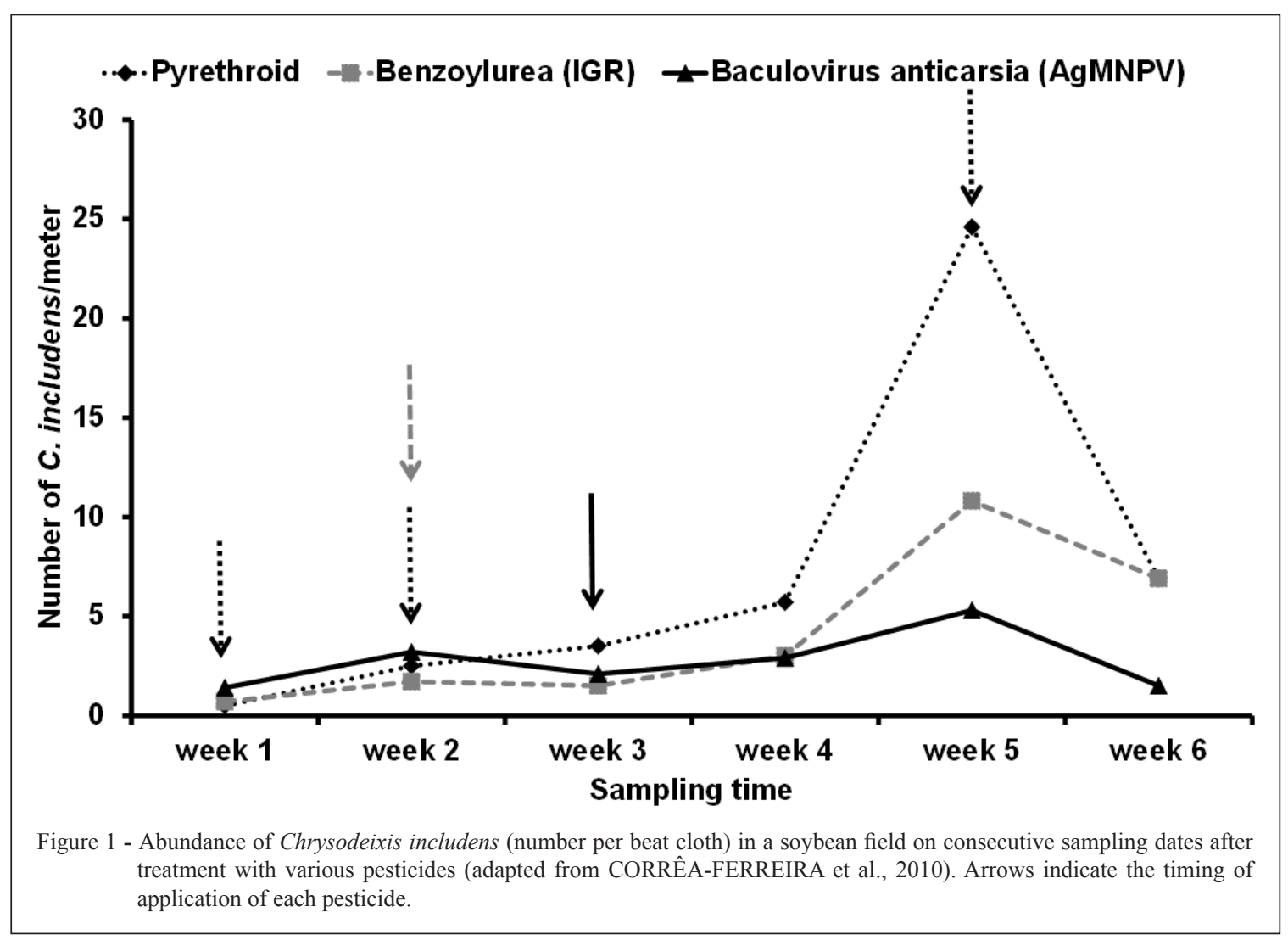

Ciência Rural, v.47, n.6, 2017. 
to field recommendation will be addressed in more detail in this review.

\section{RESULTS AND DISCUSSION}

In order to classify a chemical as selective or harmful to beneficial arthropods, it is of great importance to consider a variety of aspects using a well-established methodology (HASSAN et al., 2000; BUENO \& BUENO 2012). In this context, the International Organization of Biological Control (IOBC) was established in 1974 to study pesticide selectivity to beneficial organisms. Since then, the IOBC has promoted studies to standardize selectivity tests, and has solved or reduced most of the problems related to differences in methodology. Nevertheless, diverging results continue to be reported, and consequently prevent growers from considering selectivity when deciding on the pesticide to be sprayed.

a) Impact of different development stages: The same product used at the same rate can range from harmless to harmful, depending on the developmental stage of the natural enemy (SOUZA et al., 2014). For example, the insecticide bifenthrin $5 \mathrm{~g}$ a.i. $\mathrm{ha}^{-1}$ did not reduce the emergence of Trichogramma pretiosum Riley (Hymenoptera: Trichogrammatidae) from pupae that received this treatment, compared with the control (CARMO et al., 2010b; Figure 2A), and was classified as harmless (class 1) according to IOBC protocols (HASSAN et al., 2000). However, the same treatment, when tested on parasitoid adults drastically reduced parasitism 1 and 2 days after parasitoid contact with the insecticide (Figure 2A). It was therefore classified as harmful (class 4) to adults according to the same methodology (HASSAN et al., 2000). Similarly, CARVALHO et al. (2011) reported that bifenthrin $\left(0.02 \mathrm{~g}\right.$ a.i. $\left.\mathrm{L}^{-1}\right)$ was harmless (class 1$)$ to eggs of Ceraeochrysa cubana (Hagen) (Neuroptera: Chrysopidae) but caused an adult mortality of approximately $60 \%$ for that species (slightly harmful, class 2). Other chemicals, such as herbicides were also reported to differentially impact the response of $T$. pretiosum, depending on its developmental stage: glyphosate 3888 g a.i. ha ${ }^{-1}$ (Roundup Transorb ${ }^{\circledR}$ $6 \mathrm{~L} \mathrm{ha}^{-1}$ ) was harmless (class 1) to immature stages of $T$. pretiosum but moderately harmful (class 3 ) to adults (GIOLO et al., 2005; NÖRNBERG et al., 2008; Figure 2B). Higher tolerance of parasitoid pupae to pesticides in comparison with adults might be linked to the location of the parasitoid inside the host egg, which is protected against insecticide contact by the chorion (STECCA et al., 2016). The ability of a product to penetrate the chorion of an insect egg may be related to their physicochemical properties. For example, chemicals with higher molecular weight have greater difficulty in crossing the chorion (STOCK \& HOLLOWAY, 1993), which may also explain the higher tolerance of $C$. cubana eggs to bifenthrin compared with adults of the same species. However, such a protective function of the chorion is not supported by all published reports. Different results are reported for different chemicals, for example for spinosad. This insecticide reduced the emergence of $T$. pretiosum from pupae treated with spinosad $24 \mathrm{~g}$ a.i. ha ${ }^{-1}$, compared with the control (water) (GRANDE et al., 2016; Figure 2C) and was classified as slightly harmful (class 2), but harmless (class 1) to adults which had the same parasitism rate as control (GRANDE et al., 2016; Figure 2C).

Those differences of pesticide selectivity during different developmental stages might be related to the site of action, which can change during development and affects the rate of penetration through the integument and/or metabolization rates of the insecticides. According to FERNANDES et al. (2010), the rate of insecticide penetration through the integument results from the relationship between insecticide affinity, cuticle thickness and chemical composition. Lipophilicity of insecticides is inversely proportional to their solubility in water. Therefore, compounds of higher lipophilicity can penetrate the insect body at higher rates due to their similarity with the cuticle, resulting in different penetration rates of spinosad, glyphosate, bifenthrin or any other chemical in pupae and adults of the same parasitoid species. Moreover, even inside the host egg, parasitoid sensitivity to chemicals can vary depending on the parasitoid developmental stage. Lambda-cyhalothrin triggered higher mortality of the egg-larval stage $(0-24 \mathrm{~h}$ after parasitism) of $T$. pretiosum compared with its pre-pupae (72-96h after parasitism) or pupae (168-192h after parasitism) (CÔNSOLI et al., 1998; Figure 2D). Trichogramma pretiosum pupae (seven days after parasitism) are significantly more tolerant to chlorpyrifos $400 \mathrm{~g}$ a.i. ha ${ }^{-1}$ compared with younger parasitoid stages (the egg-larval stage of $T$. pretiosum: one day after parasitism, or $T$. pretiosum pre-pupae: three days after parasitism) (HOHMANN, 1991, Figure 2D).

Insect growth regulators (IGRs) form another group of insecticides usually classified as harmless to natural biological control agents (SILVA et al., 1988). Lufenuron $7.5 \mathrm{~g}$ a.i. $\mathrm{ha}^{-1}$ was classified as harmless (class 1) or slightly harmful (class 2) to Telenomus podisi Ashmead (Hymenoptera: 


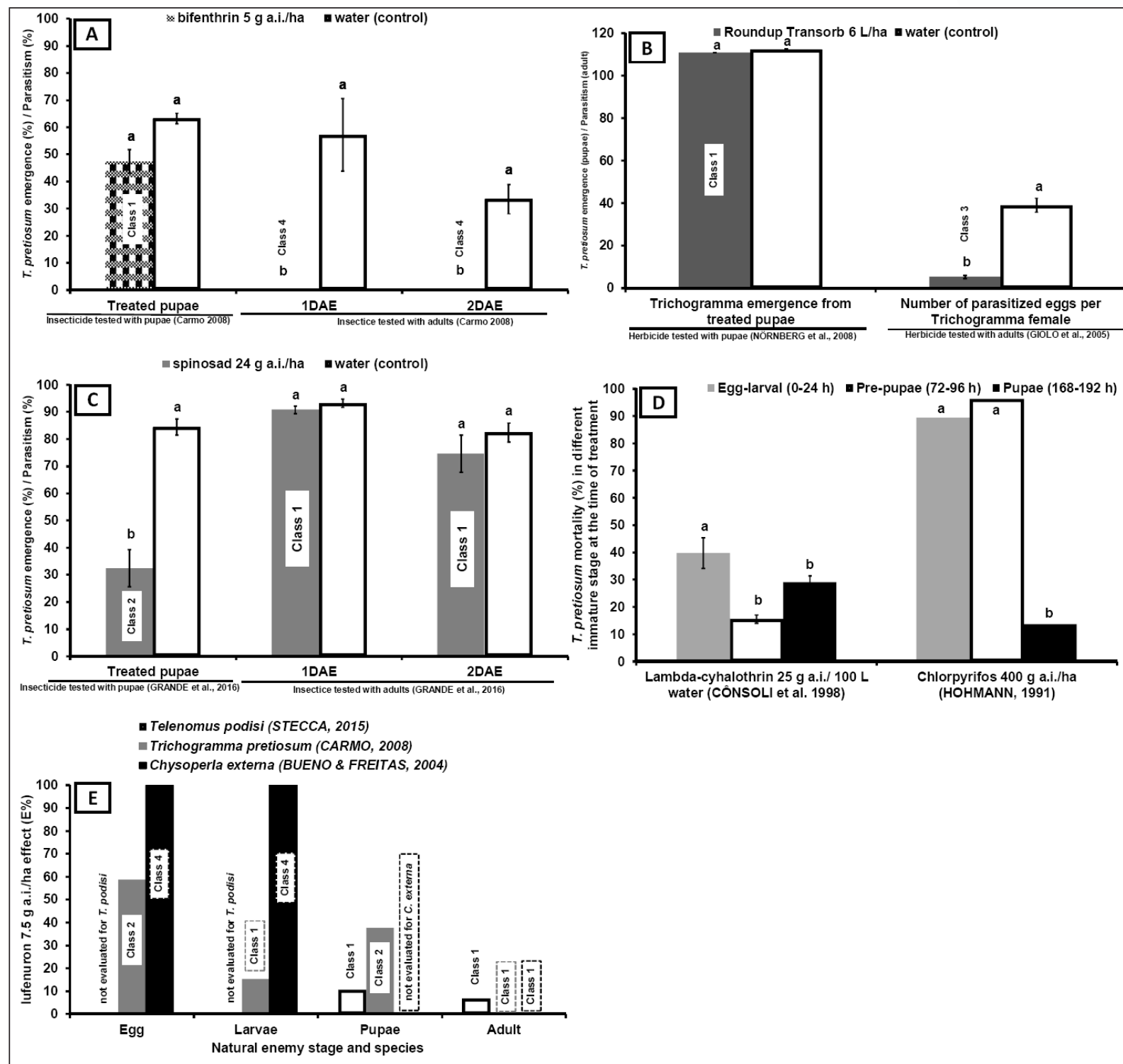

Figure 2 - Pesticide effects observed on different developmental stages of natural enemies. Bifenthrin (A), glyphosate (B), spinosad (C), lambda-cyhalothrin and chlorpyrifos (D) applied to Trichogramma pretiosum pupae and adults, and lufenuron (C) applied to various developmental stages of Telenomus podisi, T. pretiosum, and Chrysoperla externa. Means \pm SE followed by the same letter in each trial were not statistically different according to Tukey's test $(\mathrm{P}>0.05)$. E= Effect of each pesticide on the natural enemy calculated according to IOBC protocols. Classes: $1=$ harmless $(\mathrm{E}<30 \%), 2=$ slightly harmful $(30 \leq \mathrm{E} \leq 79 \%), 3=$ moderately harmful $(80 \leq \mathrm{E} \leq 99 \%), 4=$ harmful $(\mathrm{E}>99 \%$ ) (HASSAN et al., 1985).

Platygastridae) (STECCA, 2015) and T. pretiosum (CARMO, 2008), regardless of their development stage (Figure 2E). Similarly, lufenuron (0.04g a.i. $\left.\mathrm{L}^{-1}\right)$ was harmless (class 1) to the parasitoid when applied to host eggs exposed to T. pretiosum parasitism 1, 24 and 48 hours after insecticide spraying (CARVALHO et al., 2010). However, lufenuron $7.5 \mathrm{~g}$ a.i. $\mathrm{ha}^{-1}$ was classified as harmful (class 4) to eggs and larvae of the predator Chysoperla externa Hagen (Neuroptera: Chrysopidae) (BUENO \& FREITAS, 2004; Figure 2E) and as harmless (class 1) to adults of the same species (Figure 2E) according to IOBC protocols.

Selectivity of lufenuron is not only specific to the developmental stage of the beneficial arthropod, but also to the species. Even though IGRs are considered insecticides affecting only immature 
stages, lufenuron has a transovarial effect on adults of various insects (PRATISSOLI et al., 2004; ÁVILA \& NAKANO, 1999). Thus, further studies are needed to better understand the impact of lufenuron and other IGRs when ingested by parasitoid adults and several other beneficial arthropods.

b) Impact of different species: As discussed previously in this review, the action of a given pesticide may vary between species of beneficial arthropods. For example, GODOY et al. (2010) sprayed imidacloprid $0.07 \mathrm{~g}$ a.i. $\mathrm{L}^{-1}$ on adults of two species of green lacewings $(C$. externa and $C$. cubana) and reported that the compound was harmful to the first species but harmless to the second. Moreover, spinosad 24g a.i. ha ${ }^{-1}$ was classified as harmless (class 1 ) to adults of both T. pretiosum (GRANDE et al., 2016; Figure 3A) and T. podisi (STECCA, 2015; Figure 3B) but slightly harmful (class 2) and harmful (class 4) to $T$. remus (CARMO et al., 2010a; Figure 3C) according to IOBC protocols (HASSAN et al. 1985; CARMO, 2008; STECCA, 2015). Likewise, spinosad 24g a.i. ha $^{-1}$ was classified as slightly harmful (class 2) to nymphs and adults of the predator Podisus nigrispinus Dallas (Hemiptera: Pentatomidae) (STECCA, 2015; Figure 3D). In addition to being species-specific, pesticide selectivity may also depend on insect strains (CARVALHO et al., 2000). CARVALHO et al. (2000) reported that two separate strains of $T$. pretiosum were impacted differently by 18 pesticides used on tomatoes.

Species-specific differences in the response to insecticides may be related to body size: the greater the body volume, the smaller the specific area and, consequently, the lesser the exposure to insecticides (PICANÇO et al., 1997). However, this does not explain the lower impact of spinosad on $T$. pretiosum (Figure 3A) compared with $T$. remus (Figure 3C) which is slightly bigger. Similarly, this treatment caused stronger negative effects on the predator $P$. nigrispinus (Figure 3D) than on the smaller T. pretiosum (Figure 3A).

Different penetration rates of pesticides, related to physiological factors, chemical composition and thickness of the cuticle of those biological control agents mightalso help to explain the differing responses of beneficial arthropod species (FERNANDES et al., 2010). Cuticular composition of insects and chemical properties of insecticides play an important role in this context, since a more hydrophobic cuticle results in a higher affinity to insecticides and consequently, in a higher rate of penetration (LEITE et al., 1998). For example, a more lipidic (hydrophobic) cuticle of
T. remus and $P$. nigrispinus, compared with that of $T$. pretiosum and $T$. podisi might contribute to a higher tolerance to spinosad observed for the latter two species. Moreover, the tolerance of natural enemies may also be associated to higher metabolization rates of the compound and/or changes in the site of action of insecticides (FERNANDES et al., 2010). Pesticide tolerance of natural enemies may further be associated to ethion metabolization by cytochrome P450-dependent monooxygenase enzymes. These enzymes usually detoxify lipophilic compounds, converting them into metabolites and allowing their excretion (BRATTSTEN et al., 1986).

The sex ratio of natural enemies can add even more complexity to the species-specific response to pesticides. Different tolerance of males and females to organophosphate and carbamate groups in the oriental fruit fly Bactrocera dorsalis Hendel (Diptera: Tephritidae) was observed in the United States, with females being more susceptible than males (SHEARER \& USMANI, 2001). These differences might also exist in parasitoid species of the genus Trichogramma, which reproduce parthenogenetically, an issue that requires further research.

c) Impact of different pesticide rates: Insecticide field rates are increased when new, tolerant pest species are detected. For example, the bollworm H. armigera, a polyphagous pest first identified on the South American continent in Brazil during the 2012/13 crop season, was a concern for farmers across the country and led to an overuse of insecticides in an attempt to control its outbreaks (POMARI-FERNANDES et al., 2015). Labeled rates of chlorantraniliprole to control various pests range from $2 \mathrm{~g}$ a.i. $\mathrm{ha}^{-1}$ for Anticarsia gemmatalis (Lepidoptera: Erebidae) to $10 \mathrm{~g}$ a.i. ha ${ }^{-1}$ for $C$. includens. They can be as high as $30 \mathrm{~g}$ for Chloridea virescens Fabricius (Lepidoptera: Noctuidae), and probably a similar rate is needed to control $H$. armigera.

This range of applied insecticide rates also has various effects on biological control agents. While chlorantraniliprole $10 \mathrm{~g}$ a.i. ha ${ }^{-1}$ did not impact $T$. pretiosum parasitism when tested on parasitoid adults, and was thus classified as harmless (class 1) (GRANDE et al., 2016; Figure 4A), the increased rate of clorantraniliprole $30 \mathrm{~g}$ a.i. ha ${ }^{-1}$ affected T. pretiosum parasitism 2 and 3 days after spraying (DAS), and thus was classified as slightly harmful (class 2) (GRANDE et al., 2016; Figure 4A). Similarly, the increase of spinosad rates from $24 \mathrm{~g}$ a.i. ha ${ }^{-1}$ to $125 \mathrm{~g}$ a.i. $\mathrm{ha}^{-1}$ when applied to $T$. pretiosum pupae changed the classification from 


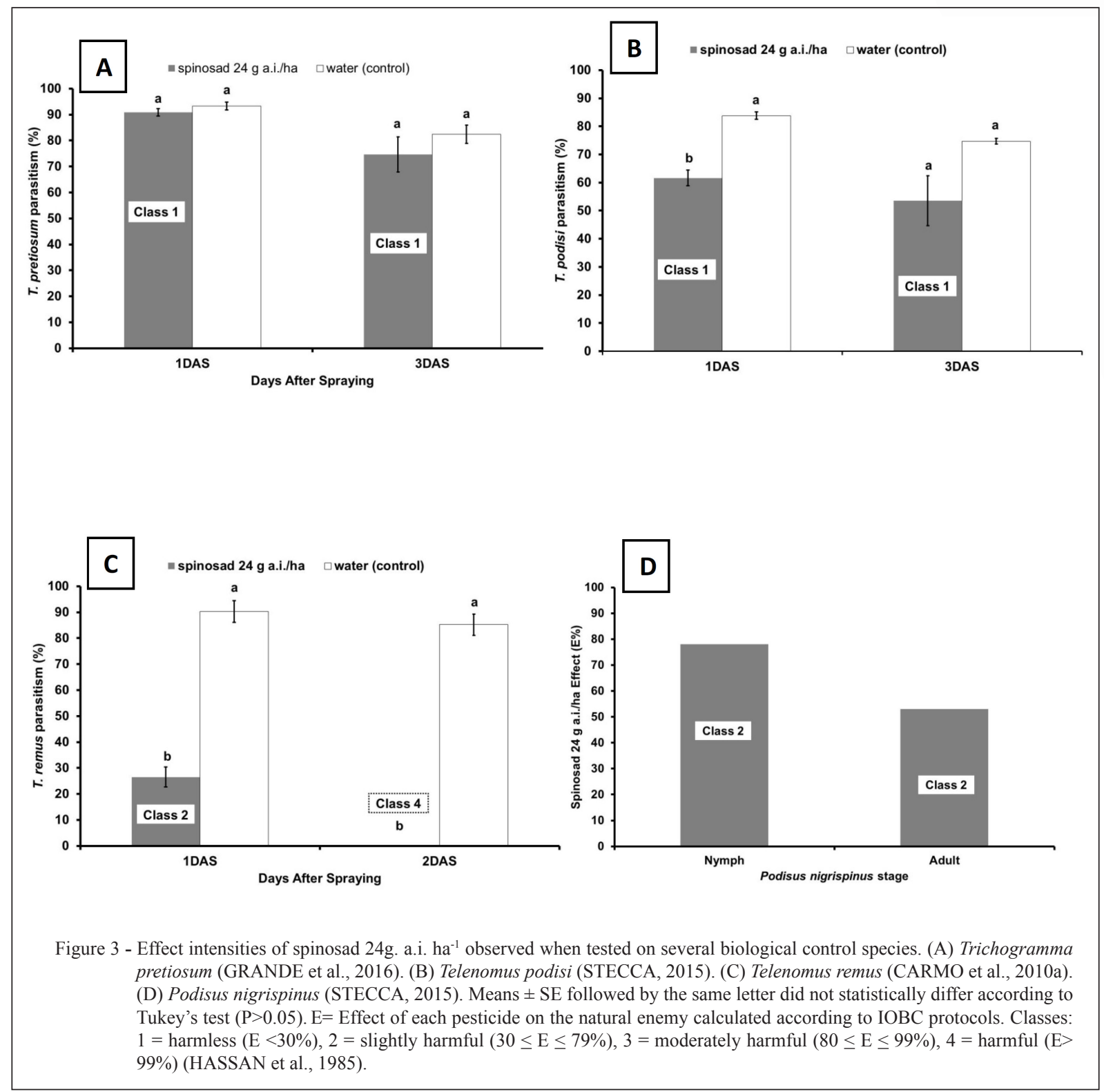

slightly harmful (class 2) to moderately harmful (class 3 ) depending on the pesticide rate (GRANDE et al., 2016; Figure 4B). Therefore, field recommendations must be very carefully made when referring to the selectivity of pesticides that depend on the applied rate, and might vary depending on the pest and even on the crop for which the pesticide is intended. Not only does pesticide selectivity depend on rate, but also on formulation (GIOLO et al., 2005). Glyphosate 1.08 grams of acid equivalent per $200 \mathrm{~L}$ of water varied from slightly harmful (class 2 ) to moderately harmful (class 3 ) when Trop $^{\circledR}$ and Roundup Transorb ${ }^{\circledR}$ were tested, respectively (STEFANELLO JÚNIOR et al., 2008; Figure 4C). This difference might be due to other chemicals present in the commercial product (inert), which might impact the beneficial arthropod (GIOLO et al., 2005).

d) Impact of the taxonomic diversity of natural enemies: Herbicides and fungicides are usually considered safe and harmless; and therefore, tend to be overused in agriculture. However, entomopathogenic fungi are among the most important natural enemies of several pests, such as caterpillars (SOSA-GÓMEZ et al., 2010). While the fungicide tebuconazol $150 \mathrm{~g}$ a.i. ha $^{-1}$ was classified as harmless (class1) or slightly harmful (class 2) to T. pretiosum and T. remus (CARMO, 2008; Figure 


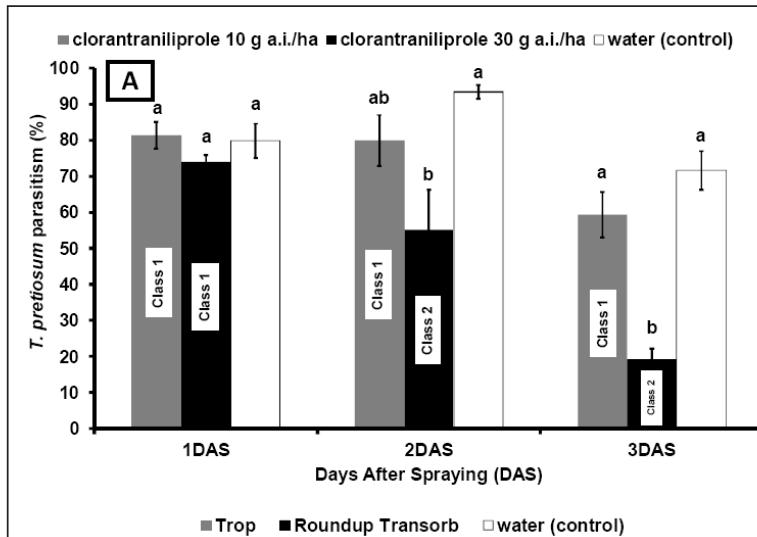

= spinosad $24 \mathrm{~g}$ a.i./ha $\quad$ espinosad $125 \mathrm{~g}$ a.i./ha $\square$ water (control)
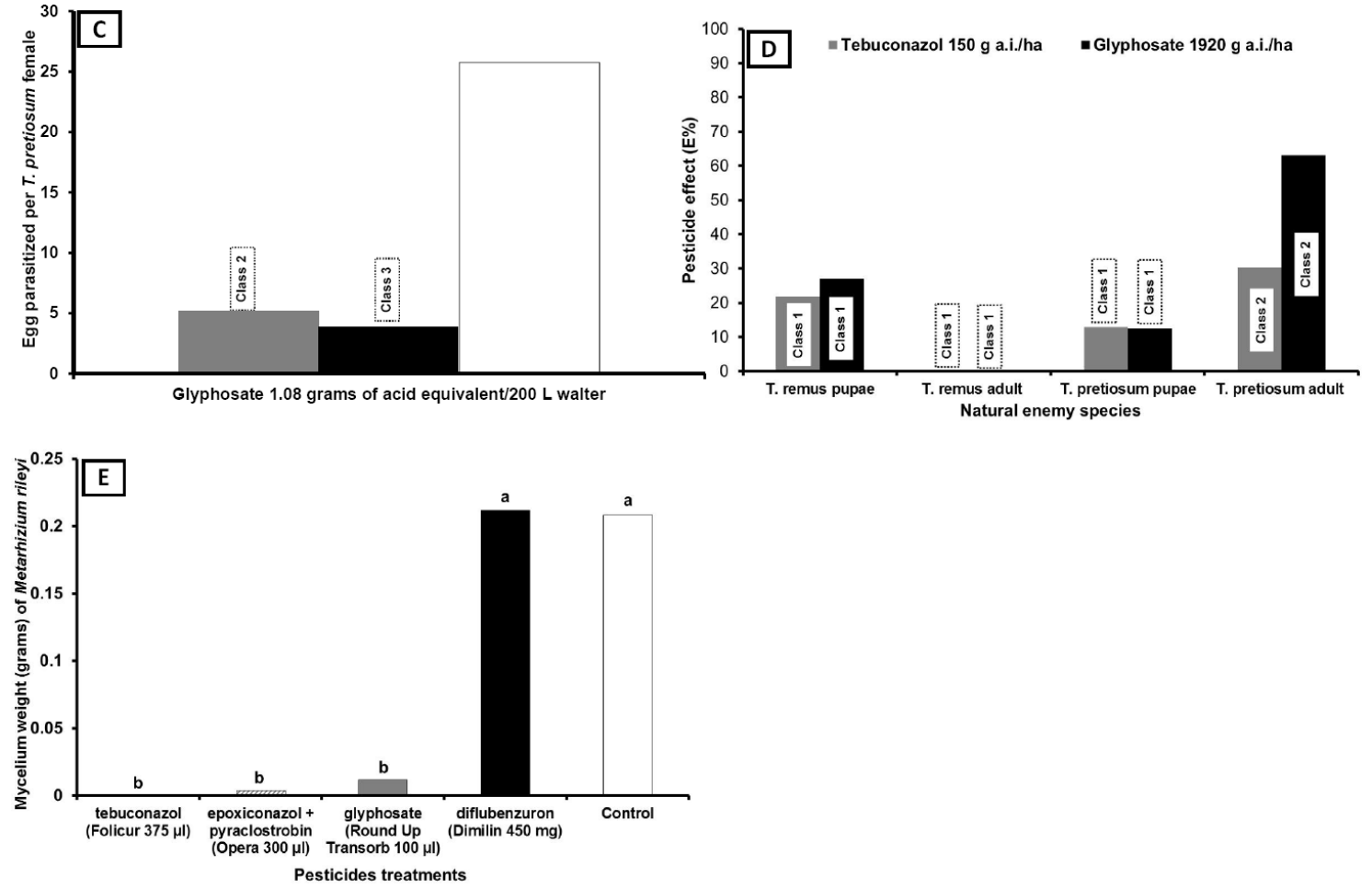

Figure 4 - Pesticide effects on natural enemies. Clorantraniliprol (GRANDE et al., 2016) (A); spinosad (GRANDE et al., 2016) (B); glyphosate (STEFANELLO JÚNIOR et al., 2008) (C); tebuconazol (CARMO, 2008) (D); and fungicides and herbicides (SOSA-GÓMEZ et al., 2010) (E). Means \pm SE followed by the same letter did not statistically differ according to Tukey's test $(\mathrm{P}>0.05) . \mathrm{E}=$ Effect of each pesticide on the natural enemy was calculated according to IOBC protocols. Classes: $1=$ harmless $(E<30 \%), 2=$ slightly harmful $(30 \leq \mathrm{E} \leq 79 \%), 3=$ moderately harmful $(80 \leq \mathrm{E} \leq 99 \%), 4=$ harmful $(\mathrm{E}>99 \%)$ (HASSAN et al., 1985).

4D), it was highly harmful to the entomopathogenic fungus Metarhizium riley (SOSA-GÓMEZ et al., 2006; Figure 4E), one of the most important natural enemies of $C$. includens in soybean crops in Brazil. This could be expected since tebuconazol is a fungicide. However, damage to these fungi is also caused by herbicides frequently used in agriculture. Some commercial glyphosate formulations also impacted $M$. riley (SOSAGÓMEZ et al., 2006; Figure 4E) but did not cause significant harm to the parasitoids $T$. pretiosum and $T$. remus (CARMO, 2008; Figure 4D).

\section{CONCLUSION}

The new challenge for research in this field (pesticide selectivity to natural biological control agentes) is to go beyond the description of lethal and sub lethal effects of pesticides on natural control agents, and also to 


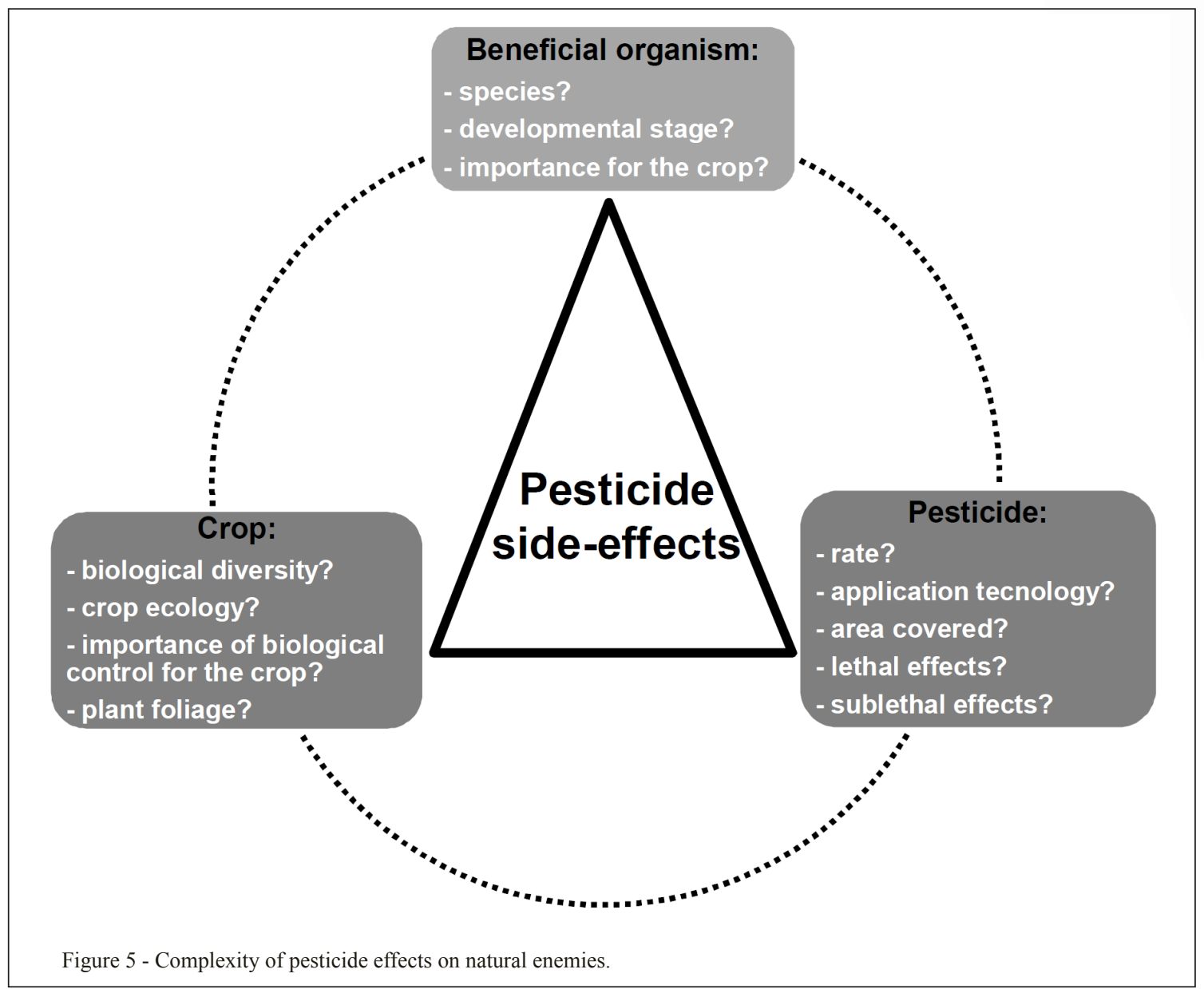

consider the ecological structure within agroecosystems. In practice, growers have to consider a complex array of questions (Figure 5) for a comprehensive evaluation of pesticide impacts. If scientific studies do not connect the various pieces of information gathered from research on pesticide effects on natural enemies, growers and consultants alone may never be able to solve the conundrum (Figure 5) of the most appropriate pesticide to be used in pest management. Therefore, we require a better knowledge of the diversity of biological control species in agroecosystems and of the different ways pesticides can affect their efficacy. An in-depth knowledge on how chemical compounds impact beneficial organisms is essential to overcome the challenges and constraints for research of pesticide effects on natural enemies and resulting field recommendation.

\section{REFERENCES}

ÁVILA, CJ; NAKANO, O. Effect of the growth regulator lufenuron on reproduction of Diabrotica speciosa (Germar) (Coleoptera: Chrysomelidae) (in Portuguese). Anais da
Sociedade Entomológica do Brasil, v.28, n.2, p.293-299, 1999. Available from: $\quad<\mathrm{http} / /$ www.scielo.br/scielo.php?script=sci arttext\&pid=S0301-80591999000200012\&lng=en $>$. Accessed: July 12, 2016. doi: 10.1590/S0301-80591999000200012.

BRATTSTEN L.B. et al. Insecticide resistance: challenge to pest management and basic research. Science, v.231, p.12551260. 1986. Available from: $<\mathrm{http}: / /$ www.entomology.wisc.edu/ raffa/Research/AllPubs/Insecticide $\% 20$ Resistance/Brattsten $\% 20$ Holyoke\%20Leeper\%20Raffa\%201986\%20Science.pdf $>$. Accessed: July 25, 2016

BUENO, AF et al. Effects of integrated pest management, biological control and prophylactic use of insecticides on the management and sustainability of soybean. Crop Protection, v.30, n.7, p.937-945, 2011. Available from: <http://www.sciencedirect.com/science/ article/pii/S0261219411000640>. Accessed: July 18, 2016. doi: 10.1016/j.cropro.2011.02.021.

BUENO, A.F.; BUENO, R.C.O.F. Integrated pest management as a tool to mitigate the pesticide negative impact into the agroecosystem: the soybean example. In: JOKANOVIC, M. The impact of pesticides. Cheyenne: Academy Publish, 2012. p.165-190.

BUENO, A.F.; FREITAS, S. Effect of the insecticides abamectin and lufenuron on the eggs and larvae of Chrysoperla externa under laboratory conditions. BioControl, v.49, p.277-283, 2004. 
CARMO, E.L. Pesticide selectivity of agrochemicals used in the soybean crop to the parasitoids of Trichogramma pretiosum (Hymenoptera: Trichogrammatidae) and Telenomus remus (Hymenoptera: Scelionidae) in laboratory conditions (in Portuguese). 2008. 88f. Dissertação (Mestrado em Produção Vegetal) - Universidade de Rio Verde, Rio Verde, GO.

CARMO, E.L. et al. Pesticide selectivity for the insect egg parasitoid Telenomus remus. BioControl, v.55, n.4, p.455-464, 2010a. Available from: <http://link.springer.com/article/10.1007/ s10526-010-9269-y>. Accessed: July 18, 2016. doi: 10.1007/ s10526-010-9269-y.

CARMO, E.L. et al. Selectivity of pesticides used in soybean to Trichogramma pretiosum Riley, 1879 (Hymenoptera: Trichogrammatidae) (in Portuguese). Arquivos do Instituto Biológico, v.77, p. 283-290, 2010 b.

CARVALHO, G.A. et al. Toxicity of acaricides to eggs and adults of Ceraeochrysa cubana (Hagen, 1861) (Neuroptera: Chrysopidae) (in Portuguese). Ciência e Agrotecnologia, v.35, n.1, p.165-171, 2011. Available from: <http://www.scielo.br/scielo. php? script $=$ sci_arttext\&pid $=$ S1413-70542011000100021\&lng= en\&nrm=iso\&tlng=pt>. Accessed: July 25, 2016. doi: 10.1590/ S1413-70542011000100021.

CARVALHO, G.A. et al. Selectivity of growth regulators and neonicotinoids for adults of Trichogramma pretiosum (Hymenoptera: Trichogrammatidae). Revista Colombiana de Entomologia, v.36, p.195-201, 2010.

CARVALHO, G.A. et al. Selectivity of some pesticides to two strains of Trichogramma pretiosum Riley, 1879 (Hymenoptera: Trichogrammatidae) (in Portuguese). Ciência e Agrotecnologia, v.25, p.583-591, 2000

CÔNSOLI, F.L. et al. Side-effects of insecticides used in tomato fields on the egg parasitoid Trichogramma pretiosum Riley (Hymenoptera: Trichogrammatidae), a natural enemy of Tuta absoluta (Meyrick) (Lep., Gelechiidae). Jornal of Applied Entomology, v.122, p.43-47, 1998. Available from: <http:// onlinelibrary.wiley.com/doi/10.1111/j.1439-0418.1998.tb01459.x/ epdf>. Accessed: July 18, 2016.

CORRÊA-FERREIRA, B.S. et al. Pest management practices used in soybean and their impact on the crop (In Portuguese). Londrina: Embrapa Soja, 2010. 15 p. (Embrapa Soja. Circular Técnica, 78). Available from: <https:/www.embrapa.br/busca-de-publicacoes/-/ publicacao/859434/praticas-de-manejo-de-pragas-utilizadas-na-sojae-seu-impacto-sobre-a-cultura>. Accessed: July 18, 2016.

FERNANDES, F.L. et al. Impact and selectivity of insecticides to predators and parasitoids. EntomoBrasilis v.3, p.1-10, 2010.

GIOLO, F.P. et al. Selectivity of glyphosate formulations to Trichogramma pretiosum (Hymenoptera: Trichogrammatidae) (in Portuguese). Planta Daninha, v.23, p.457-462, 2005. Available from: <http://www.scielo.br/scielo.php?pid=S0100$83582008000200010 \&$ script $=$ sci arttext $>$. Accessed: June 24 2009. doi: 10.1590/S0100-83582008000200010.

GODOY, C.V. et al. Brazilian soybean pest management and threats to its sustainability. Outlooks on Pest Management, v.26, p.113-117, 2015. Available from: <http://www.ingentaconnect. com/content/resinf/opm/2015/00000026/00000003/art00006>. Accessed: July 20, 2016. doi: 10.1564/v26_jun_06.
GODOY, M.S. et al. Physiological selectivity of insecticides for two species of chrysopids (in Portuguese). Pesquisa Agropecuária Brasileira, v.45, n.11, p.1253-1258, 2010. Available from: <http:// www.scielo.br/pdf/pab/v45n11/04.pdf>. Accessed: July 20, 2016.

GRANDE, M.L.M. et al. What changes in insecticide selectivity to Trichogramma pretiosum after the detection of Helicoverpa armigera in Brazil? (in Portuguese). In: REUNIÃO DE PESQUISA DE SOJA, 35, 2016, Londrina, PR. Anais... Londrina: Embrapa Soja 2016. p.73-76.

HASSAN, S.A. et al. A laboratory method to evaluate the side effects of plant protection products on Trichogramma cacoeciae Marchal (Hym., Trichogrammatidae). In: CANDOLFI, M.P. et al. (Eds.). Guidelines to evaluate side-effects of plant protection products to non-target arthropods. Reinheim: IOBC/WPRS, 2000. p.107-119.

HASSAN, S.A. et al. Standard methods to test the side-effects of pesticides on natural enemies of insects and mites developed by the IOBC/WPRS working group 'Pesticides and Beneficial Organisms'. EPPO Bulletin v.15, p.214-255, 1985.

HOHMANN, C.L. Effect of different insecticides on the emergence of Trichogramma pretiosum (Hymenoptera; Trichogrammatidae) (in Portuguese). Anais da Sociedade Entomológica do Brasil, v.20, p.59-65, 1991.

LEITE, G.L.D. et al. Selectivity of insecticides with and without mineral oil to Brachygastra lecheguana (Hymenoptera: Vespidae), a predator of Tuta absoluta (Lepidoptera: Gelechiidae). Ceiba, v.39, p.191-194, 1998.

NÖRNBERG, SD et al. Selectivity of glyphosate formulations applied in the immature stages of Trichogramma pretiosum (in Portuguese). Planta Daninha, v.26, p.611-617, 2008.

PICANÇO, M.C. et al. Selectivity of insecticides to Podisus nigrispinus predator of Ascia monuste orseis (in Portuguese). Pesquisa Agropecuária Brasileira, v.32, p.369-372, 1997.

POMARI-FERNANDES, A. et al. Helicoverpa armigera: current status and future perspectives in Brazil. Current Agricultural Science and Technology, v.21, p.1-7, 2015. Available from: <file://C:/Users/adeney/Downloads/4234-18489-1-PB.pdf>. Accessed: July 20, 2016.

PRATISSOLI, D. et al. Transovarian action of lufenuron $(50 \mathrm{G} /$ L) on adults of Spodoptera frugiperda (J. E. Smith) (Lepidoptera: Noctuidae) and its effect on the parasitoid of eggs Trichogramma pretiosum Riley (Hymenoptera: Trichogrammatidae) (in Portuguese). Ciência e Agrotecnologia, v.28, p.9-14, 2004.

SHEARER, P.W.; USMANI, K.A. Sex-related response to organophosphorus and carbamate insecticides in adult oriental fruit moth. Pest Managment Science, v.57, p.822-826, 2001.

SILVA, M.T.B. et al. Evaluation of insecticides on predators of soybean pests in ten years in Brazil (in Portuguese). Trigo e Soja, v.96, p.3-16, 1998.

SONG, F.; SWINTON, S.M. Returns to integrated pest management research and outreach for soybean aphid. Journal of Economic Entomology, v.102, p.2116-2125, 2009.

SOSA-GÓMEZ, D.R. 2006. Seletividade de agroquímicos para fungos entomopatogênicos. <http://cnpso.embrapa.br/download/ artigos/seletiv_fung.pdf $>$. Acessed: July 20, 2016 
SOSA-GÓMEZ, D.R. et al. An overwiew of arthropodassociated fungi from Argentina and Brazil. Mycopathologia, v.170, p.61-76, 2010.

SOUZA, JR. et al. Toxicity of some insecticides used in maize crop on Trichogramma pretiosum (Hymenoptera, Trichogrammatidae) immature stages. Chilean Journal of Agriccultural Research, v.74, p.234-239, 2014.

STEFANELLO JÚNIOR, G.J. et al. Selectivity of herbicides registered for maize to adults of Trichogramma pretiosum (Hymenoptera: Trichogrammatidae) (in Portuguese). Planta Daninha, v.26, p.343-351, 2008.

STECCA, C.S. Selectivity of insecticides used in soybean to Telenomus podisi (Hymenoptera: Platygastridae) and Podisus nigrispinus (Hemiptera: Pentatomidae) (in Portuguese). 2015. 63f. Tese (Doutorado em Agronomia) - Universidade Estadual de Londrina, Londrina, PR.

STECCA, C.S. et al. Side-effects of glyphosate to the parasitoid Telenomus remus Nixon (Hymenoptera: Platygastridae). Neotropical Entomology, v.45, n.2, p.192-200, Apr. 2016. Available from: <http://link.springer.com/article/10.1007/ s13744-016-0363-4>. Acessed: July 20, 2016. doi: 10.1007/ s13744-016-0363-4.

STOCK, D.; HOLLOWAY, P.J. Possible mechanisms for surfactant- induced foliar uptake of agrochemicals. Pest Science, v.38, p.165-177, 1993.

ZALUCKI, M.P. et al. The future of IPM: whither or wither? Australian Journal of Entomology, v.48, p.85-96, 2009. 